\title{
The Role of Granulocyte-macrophage Colony Stimulating Factor in Recurrent Pregnancy Losses
}

\section{Granül-makrofaj Koloni Uyarıcı Faktörünün Tekrarlayan Gebelik Kayıpları Üzerindeki Rolü}

\author{
(D) Özlem Karabay Akgül1, (D) Emre Volkan Kasımoğulları¹, (D Hakan Güraslan¹, (D Cemil Akgül2 \\ 1University of Health Sciences, İstanbul Bağcılar Training and Research Hospital, Clinic of Gynecology and Obstretrics, İstanbul, Turkey \\ 2İstanbul University, İstanbul Faculty of Medicine, Department of Gynecology and Obstretrics, İstanbul, Turkey
}

\section{Abstract}

Objective: A specific factor cannot be detected in approximately half of recurrent pregnancy losses (RPL). The aim of the present study was to investigate the role of a cytokine, granulocyte-macrophage colony stimulating factor (GM-CSF), in the etiology of recurrent pregnancy losses.

Method: A total of 50 patients who had been admitted to the gynecology and obstetrics clinics of İstanbul University Medical School between January 1995 and September 2001 were included into the study and allocated to five groups including control and study groups. The study groups included 30 patients and the control groups included 20 patients. There were 3 study groups including non-pregnant women who had abortion (2 groups) and a spontaneous abortion group, which were selected among the recurrent pregnancy loss (RPL) subjects with unknown etiology. The spontaneous abortion, non-pregnant RPL group and pregnant RPL group were accepted as study group). These groups were compared with the control groups, which included pregnant and non-pregnant healthy women.

Results: Moderate and severe GM-CSF activity was detected in the decidua of all cases in fertile and elective termination groups. However no significant difference was detected in the surface epithelium, gland epithelium and stromal GCSF activities. Endometrial GM-CSF activity was determined to decrease in spontaneous abortion and RPL cases.

Conclusion: Reduced GM-CSF activity in the decidua may have a role in the etiology of RPL. Besides, the level and distribution of GM-CSF in different compartments of the decidua may be a determinant factor in the prognosis of pregnancy.

Keywords: Recurrent pregnancy loss, GM-CSF, endometrium

\section{Öz}

Amaç: Bu çalışma ile öncelikle implantasyon için önemli bir role sahip olduğu düşünülen GM-CSF'ün tekrarlayan gebelik kaybı (TGK) etiyolojisindeki yerini araşıırmayı amaç edindik. İmplantasyon başlangıcı ve devamlıı̆ı birçok karmaşık olgunun bir senkronizasyon içinde seyrini gerektirir. Tekrarlayan gebelik kayıplarının ortalama yarısı açıklanamaz durumda olup lokal immun faktörler ile ilişkili olabileceği ile ilgili çalışmalar yoğunluk kazanmaktadır. Düşüğün fizyopatolojisinde GM-CSF'nin bir sitokin olarak rolü henüz araştııımaktadır.

Yöntem: İstanbul Tıp Fakültesi Kadın Hastalıklarıve Doğum Poliklinikleri'ne başvuran 50 olgudan kontrol ve çalışma grupları oluşturarak toplam beş grup araştırılmıştır. Çalışma grupları 30, kontrol grupları ise 20 hasta içermektedir. Çalışma grupları rutin TGK araştırması sonucu nedeni bulunamayan olgular arasından seçilen, gebe olmayan ve düşük yapanlar olmak üzere oluşturulan iki grup ile spontan düşük yapan bir başka grup beraber olmak üzere toplam olarak üç grup halinde çalışılmıştır. Bu gruplar, gebe olan ve olmayan sağlıklı kadınlardan oluşturulan kontrol grupları ile mukayese edilmişlerdir.

Bulgular: Bu çalışma göstermiştir ki spontan ya da TGK olgularında gebelikten bağımsız olarak endometriumda GM-CSF azalmış düzeyde bulunmaktadır. Söz konusu durum gebeliğin henüz gerçekleşmediği preimplantasyon endometriumunda söz konusu patolojinin bir devamlılık göstererek düşük için predispozisyon oluşturduğu tezini destekler görünmektedir. Çalışma gruplarında GM-CSF'ye ilişkin boyanma kontrol gruplarına kıyasla anlamlı derecede azalmış bulunurken, özellikle yüzey epiteli ve glandüler epitele ait farklılıklar dikkat çeker nitelikte idi. Kontrol grupları arasında farklı bir boyanma paterni izlemedi.

Sonuç: GM-CSF'nin tekrarlayan gebelik kayıplarındaki rolü immun mediatörler ve sitokinler hakkındaki bilgilerin yoğunlaşması ile daha da açıklık kazanacaktır. Bu tez çalışmasının immunodistrofik etkeninin araştıııması konusunda bir adım olarak kabul edilerek daha büyük hasta grupları ile ve prospektif yeni, detaylı çalışmalara gereksinim olduğu düşüncesindeyiz.

Anahtar kelimeler: Tekrarlayan gebelik kaybı, GM-CSF, uterus mukozası

Address for Correspondence: Özlem Karabay Akgül, University of Health Sciences, İstanbul Bağcılar Training and Research Hospital, Clinic of Gynecology and Obstretrics, İstanbul, Turkey E-mail: ozlem74akgul@hotmail.com ORCID: orcid.org/0000-0003-0313-1893 Received: 15.07.2019 Accepted: 20.08.2019

Cite this article as: Karabay Akgül Ö, Kasımoğulları EV, Güraslan H, Akgül C. The Role of Granulocyte-macrophage Colony Stimulating Factor in Recurrent Pregnancy Losses. Bagcilar Med Bull 2019;4(3):61-66

${ }^{\odot}$ Copyright 2019 by the Health Sciences University, Bagcilar Training and Research Hospital Bagcilar Medical Bulletin published by Galenos Publishing House. 


\section{Introduction}

Recurrent pregnancy loss (RPL) was defined as the loss of three consecutive pregnancies independently from being intrauterine pregnancies in $2006(1,2)$. Later in 2013, loss of two or more failed clinical pregnancies, which were documented with ultrasonography and histopathological examination, was accepted as RPL considering that every sequential abortion would increase the likelihood of the failure of the next pregnancy depending on prospective studies (3). Early pregnancy loss is the most common complication of pregnancy and seen in about $10-15 \%$ of the clinical pregnancies under 20 weeks (4). Despite the fact that the etiology is unclear in about half of the RPLs although anatomical, hormonal and genetic factors have been accounted for (5).

The presence of cytokines is required for communication and synchronization besides oocyte, sperm, embryo, and an appropriate endometrium for a successful pregnancy. Cytokines and growth factors that are produced by endometrial tissue and trophoblastic cells play a role in regulation and differentiation of trophoblastic cell growth and myometrial invasion of trophoblasts (6). Colony stimulating factors (CSF) are glycoproteins, which affect the cellular differentiation and proliferation through binding to specific receptors in hematopoietic stem cells. Members of the CSF family have different gene locations, structures and receptors.

The aim of the present study was to investigate the role of Granulocyte-macrophage colony stimulating factor (GM-CSF), which is a member of the CSF family known to have a role in continuity of pregnancy together with ovulation and implantation in the etiology of recurrent early pregnancy losses and implantation failure.

\section{Material and Methods}

A total of 50 patients aged between 18-40 years, who were menstruating regularly, who knew the last date of menstruation, who were pregnant with shorter than 20 weeks of gestation, who had experienced two or more abortions and who had presented to the İstanbul University Medical School Clinic of Gynecology and Obstetrics between January 1995 and September 2001, were included in the study, retrospectively.

A detailed anamnesis was obtained from all patients and analyses were performed for complete blood count, urine analysis, blood group, fasting plasma glucose (4-hour oral glucose tolerance test with 100 gr glucose for risky patients), hysterosalpingograph (HSG), biopsy with endometrial pipelle, thyroid stimulant hormone (TSH), prolactin, aPTT, anti-cardiolipin antibody (aCL), IgM and IgG levels, karyotype detection for the couples and genetic counseling was given. The patients were recommended contraception with the barrier method during the tests.

Fifty patients were allocated to five groups as the fertile group (control 1 - group I), the elective termination group (control 2 - group II), the spontaneous abortion group (group III), the non-pregnant RPL group (RPL 1- group IV) and the pregnant RPL group (RPL 2 - group V) with 10 patients in each.

The patients who had at least one live and healthy child, those who did not have an additional endometrial pathology and those who had cervical polyps were assigned to the "fertile group"; the patients who met these criteria and who knew the date of the last menstruation, those who had electively terminated their singleton pregnancy, those who had at least one live and healthy child were assigned to the "elective termination group". While endometrial biopsy was performed with pipelle following cervical polyp extirpation during the late secretory phase (between days 24-27 of the last menstruation) in patients in the fertile group, curettage material was obtained from the patients in the elective termination group. The patients who had been diagnosed with spontaneous abortion (impaired pregnancy, missed abortion, non-embryonic pregnancy) within the recent 2 years, those who had a history of at least one pregnancy above 20 weeks or those who had at least one live birth previously were included in the "spontaneous pregnancy group" and the curettage material of these patients were analyzed. The first RPL group (RPL 1) was composed of patients who previously had RPL with an unknown etiology (anatomical, genetic, endocrinological and autoimmune). Endometrial sampling was carried out with pipelle 2-3 days before the estimated day of menstruation. The second RPL group (RPL 2) was composed of patients who were pregnant and had RPL with an unknown etiology (impaired pregnancy, non-embryonic pregnancy, missed abortion) and abortion material was obtained.

The tissue samples were fixed within $4 \%(\mathrm{w} / \mathrm{v})$ formalin for 12-18 hours; they were dehydrated and embedded into paraffin blocks. Tissue samples were cut into pieces $5 \mu \mathrm{m}$ in thickness and placed onto clean lams, deparaffinized with xylene and alcohol, and washed with phosphate buffer solution (PBS). The tissue sections were then mixed with 
$3 \%(\mathrm{w} / \mathrm{v}$ ) hydrogen peroxide for $45 \mathrm{~min}$ in order to block endogenous peroxidase activity and treated with blocking agent, Vectastain Elite ABC kit in order to block nonspecific avidin-biotin binding. The tissue samples were incubated with $10 \mu \mathrm{g} / \mathrm{mL}$ anti-GM-CSI, which was diluted with $0.1 \%$ $(\mathrm{w} / \mathrm{v})$ bovine serum albumin at $\mathrm{pH} 7.4$ for 2 hours.

The control samples were composed of sections that did not contain primary antibody, which were incubated in GM-CSF antibody pre-absorbed with GM-CSF purified mice IgG1 and GM-CSF. Following the washing with PBS, tissue samples were incubated with secondary antibody against mice IgG was conjugated with peroxidase for one hour, centrifuged with PBS for $5 \mathrm{~min}$ and incubated with diaminobenzidine (DAB). The sections were dehydrated and slides were prepared by using permanent. The results were evaluated visually through comparing each positive sample with its control.

\section{Statistical Analysis}

The endometrial surface, the endometrial gland epithelium, and the endometrial stromal cells were evaluated separately. The fields in which immunoreactivity was most widespread and most intense were detected on small magnification (X40, X100). The location and severity of immunoreactivity were evaluated on high magnification (X250, X400). All sections were scored between 0 and 4 according to the severity of the reaction. The non-parametric statistical analyses were performed using the Fischer's chi-square test and a p level of $<0.05$ was accepted as statistically significant. The results were evaluated by comparing three different compartments of decidual tissue.

\section{Results}

The fertile and the elective termination groups were accepted as the control groups. The mean age was 29 in the control groups. The spontaneous abortion, the non-pregnant RPL group and the pregnant RPL groups were accepted as the study group. The mean age was 32 years in the study group. The mean age was similar in the control and the study groups. While six patients in non-pregnant RPL group had 3 consecutive abortions, two patients had 4 , and the remaining two patients had five abortions.

Moderate-severe GM-CSF immunoreactivity was determined in the decidua of all cases in the fertile and the elective termination groups. However, the surface epithelium, the gland epithelium and the stromal GM-CSF activity did not differ significantly in those healthy subjects regardless of the presence of pregnancy. When compared with the spontaneous abortion and the RPL groups, the GM-CSF activity of the surface epithelium and gland epithelium was found to be significantly higher in the fertile and the elective termination groups $(\mathrm{p}<0.001)$.

Stromal cell GM-CSF immunoreactivity was found to be statistically similar in all groups, although stromal cell GM-CSF expression was determined to be high in the fertile groups. Superficial, glandular epithelium and stromal cell GM-CSF activity showed a significant difference in the spontaneous abortion, the non-pregnant RPL and the pregnant RPL groups. According to the results of our study, the GM-CSF expression was affected as the staining intensity was lost in the presence of a history of spontaneous abortion or RPL (Table 1); however, the presence or absence of pregnancy did not affect the degree of staining loss (Table 1).

Table 1. Statistical comparison of recurrent pregnancy lose groups

\begin{tabular}{llll} 
Group & Surface epithelium $(\mathbf{p})$ & Gland epithelium $(\mathbf{p})$ & Stroma $(\mathbf{p})$ \\
\hline Fertile group-elective termination group & 0.8 & 0.8 & 0.9 \\
Fertile group-spontaneous abortion group & $* 0.0001$ & $* 0.0005$ & $* .18$ \\
Fertile group-non-pregnant RPL group & $* 0.04$ & $* 0.04$ & $* 0.04$ \\
Fertile group-pregnant RPL group & $* 0.05$ & $* 0.01$ & $* .4$ \\
Elective termination group-spontaneous abortion group & $* 0.001$ & $* 0.001$ & 0.8 \\
Elective termination group-non-pregnant RPL group & $* 0.05$ & $* 0.04$ & $* 0.09$ \\
Elective termination group pregnant RPL group & $* 0.004$ & $* 0.05$ & 0.8 \\
Spontaneous abortion group-non-pregnant RPL group & 0.2 & 0.1 & 0.3 \\
Spontaneous abortion group-pregnant RPL group & 0.5 & 0.5 & 1 \\
Non-pregnant RPL group-pregnant RPL group & 0.8 & 0.8 & 0.4
\end{tabular}

$\mathrm{p}<0.05$ (significant)

RPL: Recurrent pregnancy lose

All patients of fertile and elective termination groups have moderate-severe GM-CSF immunoreactivity. However, in healty patients there aren't any differences among surface epithelial, gland epithelial and stromal immunoreactivity 
While the staining in the spontaneous abortion, pregnant and the non-pregnant RPL groups was significantly different from the staining in the fertile and the elective termination groups, the staining features were similar in the spontaneous abortion and RPL cases.

This finding suggests that abortion and GM-CSF pathology have a synchrony without showing a quantity difference regardless of the etiology.

\section{Discussion}

The CSF family is composed of three members including CSF 1 (macrophage CSF/M-CSF), CSF 2 (GM-CSF), CSF 3 (Granulocyte CSF/G-CSF). The main role of the CSF family is leukocyte proliferation and differentiation. They are of glycoprotein structure. They are encoded on different chromosomes despite belonging to the same family. While G-CSF is encoded from the single gene on chromosome 17 (7), GM-CSF is encoded from chromosome 5 (8).

Cytokines have been known to have effects on the reproductive system and known to be important for maternal-fetal communication since the 1970s (9). The CSF family has immune trophic, anti-apoptotic and immune modulatory effects in early pregnancy (10). CSFs have begun to be used for therapeutic purposes in assisted reproductive technology for women who have implantation failure and folliculogenesis problems due to their effect in pregnancy formation and in the early period.

In 1991, CSFs (particularly GM-CSF) were shown by Croy et al. to be present in the placenta, the decidua and the endometrium besides ovary and follicles. (11)

CSFs play a role in a successful implantation through creating a T-helper 2 dominant environment. Implantation occurs in the early period through a local tolerance development against the fetus. Although all CSFs show an immune modulatory effect, GM-CSFs show a local effect through regulating cytotoxicity of natural killer cells and reducing the interleukin production. GM-CF plays the main role in implantation (12). GM-CSF was also shown by Clark et al. (13) to play a control role in uterine cell cytotoxicity. In conclusion, while neutralizing, GM-CSF increases the likelihood of spontaneous abortion, and the chance for a successful pregnancy increases with GM-CSF supplementation.

In addition to its local immunological effects, the CSF family is necessary for a successful pregnancy due to having an angiogenic effect. The CSF family is required not only for the decidua, but also for placental development. GM-CSF is a promoter for placental growth and enables trophoblast migration $(14,15)$.

GM-CSF may have an important role for endometrium's preparing to implantation. A healthy blastocyte, apposition, adhesion and penetration should be successful for achieving implantation. For this purpose, GM-CSF activity should be sufficient, particularly in decidual cells $(16,17)$. The role of GM-CSF as a local regulator is important, not only at the implantation stage, but also for the healthy continuation of pregnancy (18). GM-CSF, which is produced at the fetomaternal surface, contributes to placental functions and embryo development through stimulating gonadotropin production (15). The inflammatory reactions that develop when pregnancy is formed lead to alterations in cytokine concentration including GM-CSF through enabling granulocyte migration to the field.

In the present study, we determined the presence of GMCSF glycoprotein in the surface epithelium, glandular and stromal cells during the whole cycle in the fertile and the elective termination groups. The results in both groups have indicated the presence of similar amounts of GM-CSF, regardless of the presence of pregnancy (Table 1). In other words, no change occurs in GM-CSF expression in the pregnancy endometrium if there is no clinical pathology. However, the staining features of the cells have changed in the presence of a clinical pathology. The presence of GM-CSF was different in pregnant RPL2 cases and spontaneous abortion cases when compared to the elective termination group (Table 1). The cellular staining characteristic in these groups is similar to that of non-pregnant healthy RPL1 cases at all cellular levels (Table 1). No significant change was detected in stromal staining while superficial epithelium and glandular staining showed significant differences (Table 1).

GM-CSF is a local factor, which is effective on the distribution and rate of hematopoietic cells in the endometrium. Macrophages were seen to be the most effective cell group in the uterus in animal and human studies. Macrophages are cells that interact with steroid hormone levels (19). Presence of macrophage, granulocyte, and the peroxidase of some cytokines are known to be effective in eosinophilic cell concentration (20).

In the present study, GM-CSF expression was negatively affected at cellular level in patients diagnosed with RPL, and endometrial staining did not change significantly 
independent from the presence of pregnancy. In fact, endometrial GM-CSF pathology persists in a case diagnosed with recurrent pregnancy loss with unknown etiology.

The present study has indicated that an insignificantly low level of GM-CSF in stromal cells is not significantly affected by factors that lead to RPL. Moreover, protein expression in the stromal cells of the study group similar to healthy cells may indicate that GM-CSF may not necessarily be required for implantation in the very early period of pregnancy. Various mediators such as TNF $\alpha$, DDFG, TGFB and IL-1 may stimulate the GM-CSF production when the embryo passes the surface epithelium and invades the stroma $(21,22,23,24,25)$.

Much lower GM-CSF activity was shown in superficial and glandular epithelial cells in group II, group III and group V when compared to the control group (Table 1). As known, apposition and adhesion procedures are arranged by the decidual superficial epithelium and glandular elements. Defective production of GM-CSF in the decidual epithelial compartments leads to recurrent pregnancy losses through the alterations described above.

\section{Study Limitations}

The limitations of the present study are its retrospective design and the limited number of patients. Despite the presence of studies investigating GM-CSF, M-CSF (CSF-1) and TNF, they have not been studied in pre- and post-pregnancy endometrium. Presence of different concentrations of GM-CSF was investigated in this study and significant reductions in semiquantitative GM-CSF levels were determined.

\section{Conclusion}

Decidual GM-CSF activity may play a role in etiology of recurrent pregnancy losses. The level and distribution of GM-CSF in different compartments of the decidua may be a determinant in the prognosis of pregnancy. The results of the present study reveal that GM-CSF production is negatively affected in spontaneous or recurrent abortions. In other words, abnormal GM-CSF activity begins in the superficial and glandular cells of the decidua regardless of the clinical type of abortion. In addition, the abortion procedure does not affect the stromal GM-CSF production; the stromal GM-CSF production does not have a necessary role in the survey of early pregnancy.

The role of GM-CSF as a cytokine is still being investigated in the pathophysiology of abortion. The results of the present study yield information about the location and expression of GM-CSF in endometrial cells and also draw attention to its role as a cytokine in recurrent pregnancy losses with unknown etiology and indicate that further studies should be performed on this issue.

According to the results of the study, the endometrial GM-CSF level is reduced independently from pregnancy in spontaneous or recurrent pregnancy losses contrary to the intensive GM-CSF presence in endometrial layers in healthy women. In presence of a pathological pregnancy, and even in the presence of an etiology that could accompany a pathological process, GM-CSF expression on the endometrial surface and glandular epithelium decrease; however, stromal expression does not change. More comprehensive studies that would follow this preliminary study would answer the questions whether the reduction in GM-CSF expression is the etiology itself or a reflection, and could render future supplemental treatments to contribute to the clinical process.

The role of GM-CSF in recurrent pregnancy losses would be clearer through accumulating data about immune mediators and cytokines. We consider that the present study would be accepted as a step for investigating the immune dystrophic factor and further prospective studies conducted with larger patient groups are required.

\section{Ethics}

Ethics Committee Approval: Retrospective study.

Informed Consent: Retrospective study.

Peer-review: Externally peer-reviewed.

\section{Authorship Contributions}

Concept: Ö.K.A., C.A., Design: Ö.K.A., C.A., Data Collection or Processing: Ö.K.A., Analysis or Interpretation: E.V.K., H.G., Literature Search: Ö.K.A., E.V.K, Writing: Ö.K.A., E.V.K., H.G., C.A.

Conflict of Interest: No conflict of interest was declared by the authors.

Financial Disclosure: The authors declared that this study received no financial support.

\section{References}

1. RCOG. The Investigation and Treatment of Couples with Recurrent First-trimester and Second-trimester Miscarriage. Green-top Guideline [Internet] 2011. Available from: https:// www.rcog.org.uk/globalassets/documents/guidelines/gtg_17. pdf 
2. Jauniaux E, Farquharson RG, Christiansen OB, Exalto N. Evidence-based guidelines for the investigation and medical treatment of recurrent miscarriage. Hum Reprod [Internet] 2006;21:2216-2222.

3. Practice Committee of American Society for Reproductive Medicine. Definition of infertility and recurrent pregnancy loss: a committee opinion. Fertil Steril 2013;99:63.

4. Stirrat GM. Recurrent miscarriage. Lancet 1990;336:p673-p675.

5. Scott JR. Recurrent miscarriage: overview and recommendations. Clin Obstet Gynecol 1994;37:768-773.

6. Sykes L, MacIntyre DA, Yap XJ, Teoh TG, Bennett PR. The Th1:th2 dichotomy of pregnancy and preterm labour. Mediators Inflamm 2012;2012:1-12.

7. Nagata S, Tsuchiya M, Asano S, Kaziro Y, Yamazaki T, Yamomoto $\mathrm{O}$, et al. Molecular cloning and expression of cDNA for human granulocyte colony stimulating factor. Nature 1986;319:415-418.

8. Nicola NA. Hemopoietic cell growth factors and their receptors. Annu Rev Biochem 1989;58:45-77.

9. Burgess AW, Wilson EM, Metcalf D. Stimulation by human placental conditioned medium of hemopoietic colony formation by human marrow cells. Blood 1977;49:573-583.

10. Rahmati M, Petitbarat M, Dubanchet S, Bensussan A, Chaouat G, Ledee N. Colony Stimulating Factors 1, 2, 3 and early pregnancy steps: from bench to bedside. J Reprod Immunol 2015;109:1-6.

11. Croy BA, Guilbert LJ, Browne MA, Gough NM, Stinchcomb DT, Reed N, et al. Characterization of cytokine production by the metrial gland and granulated metrial gland cells. J Reprod Immunol 1991;19:149-166.

12. Orsi NM, Tribe RM. Cytokine networks and the regulation of uterine function in pregnancy and parturition. J Neuroendocrinol 2008;20:462-469.

13. Clarck DA, Chaouat G, Mogil R, Wegmann TG. Prevention of spontaneous abortion in DBA/2-mated CBA/J mice by GM-CSF involves CD8+ $\mathrm{T}$ cell-dependent suppression of natural effector cell cytotoxicity against trophoblast target cells. Cell Immunol 1994;154:143-152.

14. Bowen JM, Chamley L, Keelan JA, Mitchell MD. Cytokines of the placenta and extra- placental membranes: roles and regulation during human pregnancy and parturition. Placenta 2002;23:257273.

15. Xiong S, Sharkey AM, Kennedy PR, Gardner L, Farrell LE, Chazara $\mathrm{O}$, et al. Maternal uterine NK cell-activating receptor KIR2DS1 enhances placentation. J Clin Invest 2013;123:4264-4272.

16. Zhao Y, Chegini N. The expression of granulocyte macrophage colony stimulating fac-tor (GM-CSF) and receptors in human endometrium. Am J Reprod Immunol 199;42:303-311.

17. Tamura K, Kumasaka K, Kogo H. The expression of granulocytemacrophage colony stimulating factor (GM-CSF) and its regulation by ovarian steroids in rat uterine stromal cells. Jpn J Pharmacol 1999;79:257-262.

18. de Moraes AA, Paula-Lopes FF, Chegini N, Hansen PJ. Localization of granulocyte- macrophage colony stimulating factor in the bovine reproductive tract. J Reprod Immunol 1999;42:135-145.

19. Charnock-Jones DS, Sharkey AM, Fenwick P, Smith SK. Leukaemia inhibitory factor mRNA concentration peaks in human endometrium at the time of implantation and the blastocyst contains mRNA for the receptor at this time. J Reprod Fertil 1994;101:421-426.

20. Tabibzadeh S. Human endometrium: an active site of cytokine production and action. Endocr Rev 1991;12:272-290.

21. Kauma S, Matt D, Strom S, Eierman D, Turner T. Interleukin-1 beta, human leukocyte antigen HLA-DR alpha, and transforming growth factor-beta expression in endometrium, placenta and placental membranes. Am J Obstet Gynecol 1990;163(5 Pt 1):1430-1437.

22. Robertson SA, Mau VJ, Hudson SN, Tremellen KP. Cytokineleukocyte networks and the establishment of pregnancy. Am J Reprod Immunol 1997;37:438-442.

23. Inoue T, Kanzaki H, Iwai M, Imai K, Narukawa S, Higuchi T, et al. Tumour necrosis factor alpha inhibits in-vitro decidualization of human endometrial stromal cells. Hum Reprod 1994;9:2411-2417.

24. Ripley D, Tang XM, Ma C, Chegini N. The expression and action of granulocyte macrophage- colony stimulating factor and its interaction with TGF-beta in endometrial carcinoma. Gynecol Oncol 2001;81:301-309.

25. Clifford K, Rai R, Regan L. Future pregnancy outcome in unexplained recurrent first trimester miscarriage. Hum Reprod 1997;12:387-389. 